UNITED STATES

DEPARTMENT OF THE INTERIOR

U.S. GEOLOGICAL SURVEY

RADAR AS A COMPLEMENT TO TOPOGRAPHIC

MAPS FOR DELINEATING MARINE TERRACES

by John L. Place

Open-File Report $86-010$

Reston, Virginia

1986 


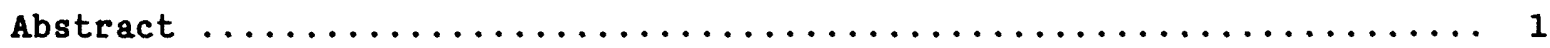

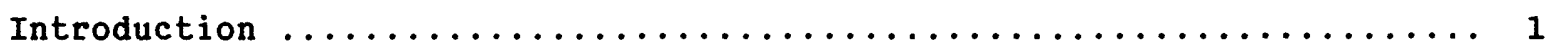

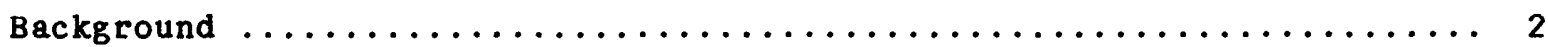

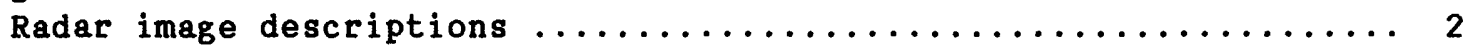

Geological survey side-looking airborne radar images ....... 2

Seasat radar images .......................... 4

Westinghouse side-looking airborne radar images .......... 4

Photogrametric equipment used in the tests $\ldots \ldots \ldots \ldots \ldots \ldots \ldots \ldots 4$

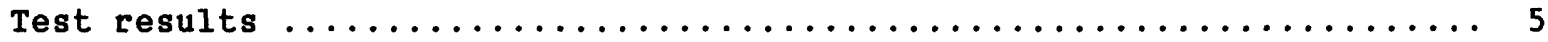

Monterey County coast, California ................... 5

Santa Cruz and Point Conception sites, California ........... 5

Seasat radar image of Point Conception area ............ 6

Sonoma County coast and Point Arena, California ............. 7

Georgia coastal plain ........................... 7

San Diego County coast, California .................... 8

Westinghouse radar images of San Diego County ........... 8

Geological Survey radar images of San Diego County ......... 8

Conclusions and recommendations $\ldots \ldots \ldots \ldots \ldots \ldots \ldots \ldots \ldots \ldots \ldots \ldots \ldots$

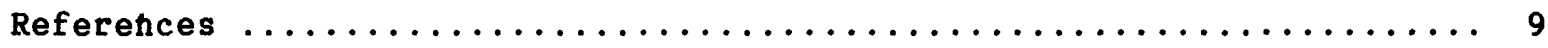

\section{ILLUSTRATIONS}

Figure 1.--Location of test sites and major cities nearby $\ldots \ldots \ldots \ldots$ 


\title{
RADAR AS A COMPLEMENT TO TOPOGRAPHIC MAPS FOR DELINEATING MARINE TERRACES
}

\author{
by John L. Place \\ U.S. Geological Survey \\ 521 National Center \\ Reston, Virginia 22092
}

\begin{abstract}
In special situations, side-looking airborne radar images can be used to complement topographic maps for locating and mapping marine terraces on mountainous coasts. When a radar image and a topographic map are superimposed in a Zoom Transfer Scope, the two data sources enhance each other to provide more information than is available from either alone. For locating marine terraces on mountainous coasts, a radar view that is parallel with the coast or looking offshore apparently produces a more interpretable image than a view straight in toward the land. This technique has not proven to be equal to field work for terrace mapping, but it should be faster and less expensive for a preliminary terrace delineation. Radar images from the seasat satellite were also tested, but without notable success; the side-looking airborne radar images were generally superior for terrace delineation.
\end{abstract}

\section{INTRODUCTION}

The U.S. Geological Survey has for several years been sponsoring airborne radar data collection for large areas of the Nation (Moore and Sheehan, 1981, and Kover and Jones, 1986). This data collection has been performed to enter the data into the public domain and to evaluate sidelooking airborne radar (SLAR) as an aid to research and mapping. SLAR imagery data are currently available for more than 25 percent of the conterminous United States and more than 20 percent of Alaska.

The investigation described herein is to determine if image interpretation is facilitated by optically overlaying radar images upon topographic maps through use of a photogrammetric device. In this case a Bausch \& Lomb Zoom Transfer Scope was used to correct geometric distortion in the radar image while superimposing it, through binocular viewing, upon a topographic map. The contour lines from the topographic map would be expected to give greater meaning to the patterns of gray tones seen on the radar image, and vice versa. In this way, subtle terrain patterns might become recognizable where they had not been when using the map or image alone.

Any use of trade names and trademarks in this publication is for identification purposes only and does not constitute endorsement by the U.S. Geological Survey. 
The terrain features studied in the tests were believed to be marine terraces. Marine terraces are remains of former wave-leveled shorelines that have been displaced by vertical movements of the land or sea surface. Because they are long linear features, radar enhancement was likely. Geologists and geomorphologists use marine terraces as a record of uplift and deformation of a surface that had once been horizontal and at a base level of elevation. Measurement of such movements sheds light on the geologic history of the area. Ancient beach deposits may also be important today for their mineral resources.

\section{BACKGROUND}

The sites selected for study were along the California coast and in the coastal plain of Georgia (fig. 1). The California sites were selected because (1) the survey had obtained side-looking airborne radar images of the coast between San Francisco and Santa Barbara in 1984-85 and the remainder of southern California in 1985-86, (2) the mountainous coast here is emergent and has several uplifted marine terraces of interest to geologists working on such topics as plate tectonics, earthquake hazards, or oil and gas exploration, and (3) a geologist, Leonard Palmer, had performed detailed mapping of the marine terraces along this coast using topographic map interpretation and field work (Palmer, 1967). One of the questions to be answered was whether the SLAR images, combined with topographic maps, would allow additional terraces to be mapped that were not detected by Palmer.

After this investigation had been proposed, it was learned that the office of Mineral Resources of the Geological Survey was interested in marine terraces in the coastal plain of the southeastern United States as potential sites of titanium ores. Titanium is one of the strategic minerals currently being sought to meet national needs. As a result, a site in Georgia was added to the investigation. An appropriate radar image was available, as well as a geologic map showing the primary terrace levels believed to be present in Georgia (Georgia Geological Survey, 1976).

\section{Radar Image Descriptions}

\section{Geological Survey Side-Looking Airborne Radar Images}

Radar images used in this study were obtained by the Aero Service Division, Western Geophysical Company of America, under contract with the Geological Survey. The radar had been built by Goodyear and was part of their Electronic Mapping System (GEMS); it is a synthetic aperture radar that operates at a wavelength of $3 \mathrm{~cm}$ ( $X$-band) with a reported resolution of 10 meters in azimuth and 12 meters in range.

The 1984-85 radar survey of the California coast was between San Francisco and the Santa Barbara Channel. The flight lines were north/ south with flight spacing of $14 \mathrm{kms}$ and image offset of $18.5 \mathrm{kms}$ at a flight altitude of 29,000 feet above datum. The radar look direction was due east. The depression angles were $25^{\circ}$ for the near edge of each swath and $9^{\circ}$ at the far edge. This produced a 60-percent sidelap on the radar image strips. Radar mosaics were constructed at a scale of $1: 250,000$ using near range strips. Available mosaics of the California coast were used in this investigation; however, for the most promising sites, the radar strips were enlarged or were used for initial screening. 

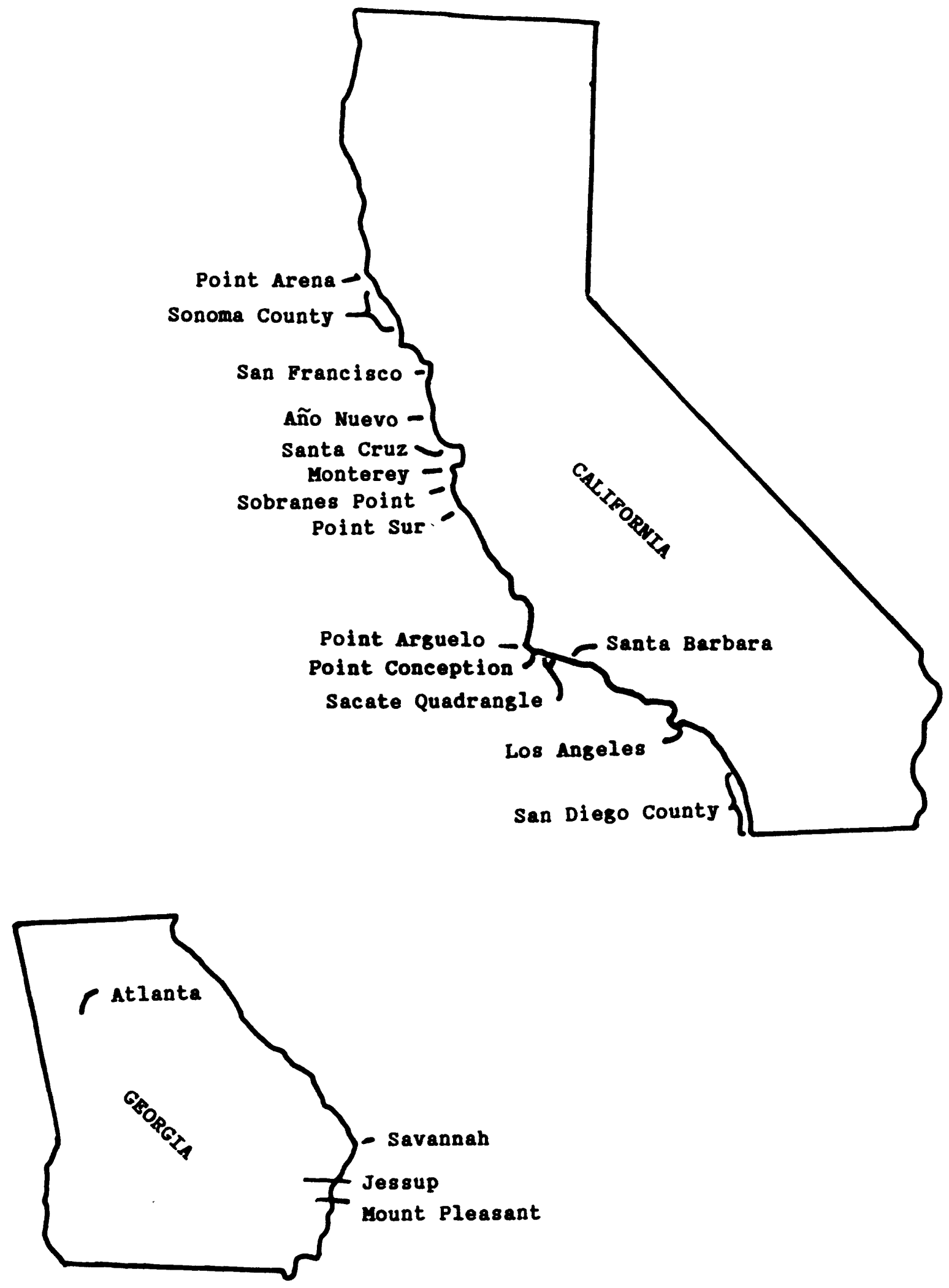

Figure 1.--Location of test sites and major cities nearby. 
In the 1985-86 radar survey of the remainder of southern California, the look direction was due west, but otherwise the specifications were the same.

\section{Seasat Radar Images}

To supplement the investigation by adding an additional type of synthetic aperture radar image that is commonly available, four digitally processed seasat radar images were obtained from the National Oceanic and Atmospheric Administration (NOAA) of the U.S. Department of Commerce. The seasat satellite functioned June to october 1977. Its imaging radar operated in the L-band $(23.5 \mathrm{~cm})$ and had a depression angle of about $70^{\circ}$ below the horizontal. Ground resolution of the image is about 30 meters. Four digitally processed images were used in this study. One of the images was of the Point Conception area which was also covered by Geological Survey SLAR images. Two others were of the California coast north and south of the Survey's SLAR coverage, and a fourth was of coastal Georgia that had not been covered by the Survey's SLAR data. The three California Seasat images were radar views looking to the northwest. The Georgia scene had a northeast look direction. These look directions were selected to reduce the obscuring effect of radar layover.

\section{Westinghouse Side-Looking Airborne Radar Images}

In 1965, the Earth Resources Survey Program of the National Aeronautics and Space Administration (NASA) in cooperation with the University of Kansas and the Geological Survey acquired Westinghouse side-looking airborne radar images of the San Diego County coast in California. A copy of this strip (Flight 102, November 1965) was provided to the Geological survey. The radar system used was the AN/APQ 97, which operated using real aperture in $\mathrm{Ka}$-band $(0.86 \mathrm{~cm})$. In this case, the radar strip contained two different polarizations, $V V$ and $V H$ (vertical transmit/vertical receive and vertical transmit/horizontal receive). This strip was added to the study to provide a contrasting look direction; in this case, east as compared with northwest for the seasat image of the same site or the west view of the Aero Service SLAR images.

\section{Photogrammetric Equipment Used in the Tests}

The Zoom Transfer Scope made by Bausch \& Lomb, Inc., allows an operator to view both an image and a map superimposed (Ambrose and McHail, 1972). A beam-splitting prism combines the images of the radar and the map and allows binocular viewing. The transfer scope has a zoom system (up to 7 $X$ magnification), an image rotational system, and a stretch system to reduce distortion.

The maps used were standard Geological survey topographic maps at scales of $1: 250,000,1: 100,000$, and $1: 24,000$. 


\section{Monterey County Coast, California}

An attempt was made to combine Geological Survey/Aero Service SLAR images with 1:100,000- and 1:24,000-scale topographic maps to enhance subtle terrace-like patterns believed to exist on the steep mountainous shoreline between Sobranes Point and Point Sur. This site had been selected because Palmer had reported the disappearance of terrace remnants here, presumably due to excessive erosion and deposition. In the Geological Survey's field check, bench-like remnants, resembling notches, were found in the slopes of promontories. It was hoped that the radar and topographic maps combined would reveal linear patterns of the benches not easily confirmed in the field. Unfortunately, the images failed to show any but the lowest terrace, and that only intermittently, and did not add to existing knowledge. Apparently the radar energy reflected off the west face of the mountains with such intensity as to mask or hide the remnant benches. The depression angles of over 20 percent, combined with precipitous slopes on the ground, may have created radar layover at the rear walls of the shallow benches.

\section{Santa Cruz and Point Conception Sites, California}

To test if better results could be achieved where the coast turned east-west, parallel to the eastward look direction of the radar, two new sites were added to the investigation at Point Conception and near Santa Cruz, both covered by the Aero Service radar mission. Initial perusal of the radar images revealed that bands of varying shades of gray border the coast both in the Point Conception area and west of Santa Cruz. However, Palmer reported that terraces were particularly well developed in both areas.

Geological Survey/Aero Service SLAR images for the coast from Santa Cruz west and north to Ano Nuevo Point were magnified and studied. The coast from Davenport east to Santa Cruz appeared to be most promising for terrace investigation. This part of the radar image was enlarged photographically to $1: 100,000$ scale and mounted in the Zoom Transfer Scope. After zoom enlargement and superimposition of the image upon a 1:24,000scale map, further adjustment of the transfer scope was possible to remove most of the remaining distortion from the image. It could be seen that the contour lines matched the gray band boundaries, showing that terrace lineaments of equal elevation existed. The lowest terrace was between 60 and 100 feet elevation, with a second just above $200 \mathrm{feet}$, and a third just above 400 feet. It is likely that these long patterns, running nearly horizontally for tens of miles, are marine terraces; however, further field study would be necessary to confirm that shore-type sediments were present and that the levelings of slope were not caused by differential erosion of horizontal strata. Comparison with Palmer's field findings showed agreement for the lowest two or three terraces. However, Palmer had reported finding several more higher benches not detected in the radar/map study. 
Farther up the coast, the northwest-southeast trending shoreline near Ano Nuevo Point did not seem promising for study because of numerous parallel fault lines of the San Gregorio Fault Zone near the shore (Jennings, 1977). These lineaments complicate the interpretation of terrace patterns in the radar image.

Another east-west trending segment of California coastline extends from Point Arguelo to Santa Barbara, encompassing Point Conception. For this site, as with the Santa Cruz site, initial perusal of the radar images revealed clearly visible bands of light and dark gray. This banding is also easily seen on Landsat images, indicating that vegetation patterns coexist with the topographic patterns. When the SLAR images are superimposed in the Zoom Transfer Scope upon the 1:24,000-scale topographic maps for the Point conception and Sacate quadrangles, contour lines tend to follow the edges of the bands, indicating that they are terraces. However, stream erosion has deeply dissected the upper terraces. The bands of gray on the radar image also correspond with strata shown on maps of surficial geology (Campbell and others, 1975, and USGS, 1969). The geology of this coast is characterized by a dip slope in which the layers of sedimentary rock are successively exposed on the seaward (southward) facing slope of the Santa Ynez Mountains. Within each of the strata in the Point Conception and Sacate quadrangles, the crests and benches on the mountain spurs are nearly level and at the same elevation, indicating an ancient leveling, possibly by wave action. The lowest terrace is continuous and ranges in elevation from 40 feet at the top of the present sea cliff to 200 feet at the back of the terrace; based upon topographic evidence, this is apparently a marine terrace. Palmer's findings in the field within the Point Conception quadrangle generally agree, but he reported higher lines of small benches, almost eroded away, not enhanced by the radar (Palmer, 1967). He also raises questions about surficial geology, i.e., the dip slope, influencing the formation of terraces.

For the sacate quadrangle, a stereopair of overlapping SLAR images (1:100,000 scale) provided an image in three dimensions; however, this technique aided only slightly the enhancement of the terraces and could not be superimposed on a map in the transfer scope.

\section{Seasat Radar Image of Point Conception Area}

Inasmuch as look direction of the radar may be important in successful enhancement of terraces, another view was obtained through use of a seasat radar image with a northwest view that showed most of Santa Barbara County including the Point Conception area. This image was at a scale of about $1: 400,000$ and when mounted in the Zoom Transfer Scope was superimposed upon the 1:100,000-scale topographic maps of the Point Conception and Santa Barbara quadrangles. Unfortunately, no new information was obtained that was not attainable previously using the airborne radar images and 1:24,000-scale maps. The Zoom Transfer Scope was limited to $7 \times$ magnification and could not enlarge from $1: 400,000$ to $1: 24,000$ scale. The radar layover was excessive in the mountains. The broad view gained by working at $1: 100,000$ scale rather than $1: 24,000$ scale was of some advantage when dealing with very long lineaments as are present here. 


\section{Sonoma County and Point Arena, California}

As a further test of the value of a view parallel with the shoreline, a Seasat radar image of the Sonoma County coast and Point Arena with a northwest look direction was obtained. In this case, a preliminary mapping of possible marine terraces had already been done by the author by interpreting topography shown on several 1:24,000-scale topographic maps and replotting on a 1:100,000-scale topographic map of the Point Arena quadrangle. The 7.5-minute quadrangles were those between Point Arena and Stewart's Point. The Zoom Transfer Scope was used to superimpose the seasat image (scale about 1:400,000) upon the terrace annotations on the 1:100,000-scale map. It was evident that the gray patterns on the radar image were showing the grassland-forest boundaries, not the terraced land forms. There was further complication by lineaments associated with the San Andreas fault zone (Jennings, 1977).

\section{Georgia Coastal Plain}

Quaternary marine terraces in the form of low broad steps have long been known to exist on the Atlantic coastal plain of Georgia and Florida. A Seasat radar image transparency, scale about 1:500,000, was superimposed in the Zoom Transfer Scope upon the standard 1:100,000-scale topographic map of the Brunswick quadrangle. This was done to gain an overview of the several terrace bluff lines in the region. The map's contour interval of 2 meters was favorable, but unfortunately showed an abundance of possible terraces. Matching the drainage networks on the map with the gray patterns on the image proved helpful in terrace delineation. The geologic map of Georgia (Georgia Geological Survey, 1976) shows the Pamlico, Talbot, Penholoway, and Wicomico shorelines. The latter three are generally discernible in the radar image.

The next step was to enlarge, photographically, parts of the image to a scale of 1:100,000 to allow them to be used on the Zoom Transfer Scope with 1:24,000-scale maps. The sector of the image selected was of the Mount Pleasant and Jessup areas, immediately south of the Altamaha River.

The Talbot shoreline has a bluff crest roughly horizontal at about 40 feet above sea level. It is parallel with the present Georgia coast and generally forms the inland boundary of Glynn County in this area. This terrace is easily seen on the 1:24,000-scale topographic maps, which have a contour interval of 5 feet. It is also easily seen on the radar image because land on the terrace is largely cleared of forest while poorly drained forest land prevails below the Talbot bluff. The radar signatures are quite different: dark for cultivated land and light gray for swamp forest (Place, 1984).

The next higher terrace, the Penholoway shoreline, is about 75 feet above sea level. It is detectable with difficulty on the topographic maps and also is difficult to discern on the radar image. Farther inland near Jessup, an even higher terrace, the wicomico shoreline at about 100 feet of elevation, is prominent on both the map and image. The superimposition of map and image in the transfer scope is helpful.

The Georgia findings are largely negative, producing little new information. The differences in radar signature appear to be caused more by vegetation than by relief. It is doubtful that the seasat radar image added any knowledge of terraces that could not have been obtained from the 1:24,000-scale topographic maps alone, except possibly a broad overview of terraces that extended for many tens of miles. 


\section{San Diego County Coast, California}

Because San Diego County is reported to possess marine terraces (Palmer, 1967), a Seasat radar image (scale 1:400,000) was obtained and superimposed upon topographic maps at a scale of $1: 100,000$ using the transfer scope. The 1:100,000-scale maps were annotated with additional terrace information drawn from the 1:24,000-scale maps. The Seasat radar image had a look direction toward the northwest which was offshore on this north-south trending coast. Unfortunately, with this view the terraces were obscured by strong radar reflection from the inland face of ancient beach ridges that covered the lower terraces up to 2 miles inland. Also, cuts and fills for highway and rail lines created prominent lineaments in the radar image. Large-scale topographic maps indicate that terraces do exist on this coast and that they climb in approximately 100foot steps to over 400 feet of elevation several miles inland. However, these steps are not evident in the seasat radar image, even when combined with contour lines in the Zoom Transfer Scope.

\section{Westinghouse Radar Images of San Diego County}

Also available for this segment of coast is an east-looking radar image strip flown in 1965 (Flight 102) by Westinghouse. The image strip has a scale of about $1: 85,000$. The collection and processing of the data were less advanced than exist today, and the aircraft flew a slightly curved course maintaining constant distance from land. Hence, there was considerable distortion in the image, which could not be corrected by the Zoom Transfer Scope. Nevertheless, overlaying of the Westinghouse radar images on 1:24,000-scale topographic maps was possible if the transfer scope was readjusted for small areas. With the view directly in toward the coast, numerous lineaments parallel with the shore were enhanced. The beach ridges were the most prominent of these and extended about 30 miles along the northern San Diego County coast. The terrace bluffs may have contributed to the radar reflection, but they were intermingled with the beach ridge patterns. The higher terraces farther inland had been heavily eroded and did not appear as lineaments in the Westinghouse side-looking radar image. The findings were true of both $V V$ and $V H$ polarizations of the radar.

\section{Geological Survey Radar SLAR Images of San Diego County}

A set of radar images of the San Diego County coast flown by Aero Service for the Geological Survey in November 1985 became available just before completion of this report. This coverage differed from previous SLAR coverage of California by having a westward look direction rather than eastward. These new radar images proved to be superior to all previously studied in this investigation in that they showed a deep shadow on the larger terrace bluffs. The more prominent terrace bluffs had been previously located by interpretation of $1: 24,000-s c a l e$ topographic maps. Palmer's maps of the marine terraces showed the same patterns (Palmer, 1967). In this case, the offshore look direction combined with an appropriate radar depression angle contributed to an effective image for interpretation of terraces. Had the depression angle been too steep, as with Seasat radar, shadows would have been negligible. Had the coast been steeper in this area, the entire seaward slope might have been shadowed. 
Nevertheless, these latest findings support the belief that an offshore or alongshore view is superior to an onshore view for delineation of terraces, at least on the California coast.

\section{CONCLUSIONS AND RECOMMENDATIONS}

The simultaneous viewing of superimposed side-looking radar image and topographic map has been found to enhance detection of possible marine terraces over what had been interpretable using either image or map separately. This finding is particularly true on mountainous coasts. This technique allows a broad view covering tens of miles on the Earth's surface. The elevation of the terraces seen in the transfer scope's viewer can be read from the topographic map superimposed. In this way, relative heights and degree of deformation from the horizontal can be measured. This technique could aid the study of geologic history.

On the negative side, marine origin of the terraces cannot be confirmed unless field work is performed. In this investigation, the image interpretation technique used did not reveal any new terraces not discovered previously by field investigators and in nearly all cases failed to reveal some high or subtle terraces found previously in the field. Radar layover and presence of fault lines and old beach ridges complicated the interpretation.

However, where travel to the field is expensive or too time consuming, it is possible to use photogrammetric equipment with simultaneous viewing capability to survey potential sites quickly and inexpensively as a first step in selecting optimum areas for field investigation. Such a preliminary survey might be done by geologists, for example, searching for mineral resources often associated with beach deposits.

This particular study showed that radar could enhance marine terraces better when looking parallel with the coast, or in some cases offshore, than when looking straight in at a steep mountainous coast. The view angle did not appear to be a problem when the coastal plain had relatively low relief, as in Georgia. It should be mentioned that the two places where the alongshore view was most advantageous, Santa Cruz and Point Conception, were south-facing coasts where a previous investigator, Leonard Palmer, had reported the marine terraces to be especially well preserved. Extensions of the same terraces may have been eroded away by the North Pacific's wave energy along west-facing coasts. In other words, the terrace enhancement may have been due less to the alongshore look of the radar than to the natural existence of broader terraces at these two places.

The photogrammetric device used in this investigation was a Bausch \& Lomb Zoom Transfer scope. Other types of image viewing equipment that can perform equivalent functions are available and could be tested in this role.

\section{REFERENCES}

Ambrose, W.R., and McHail, R.R., 1972, The Zoom Transfer Scope, a new photogrammetric instrument: Proceedings, XII Congress of the International Society for Photogrammetry, Ottawa, Ontario, Canada, $10 \mathrm{p}$. 
Campbell, R.H., Wolf, S.C., Hunter, R.E., Wagner, H.C., Junger, A., and Vedder, J.G., 1975, Geologic map and sections, Santa Barbara Channel region: U.S. Geological Survey Open-File Map 75-123.

Georgia Geological Survey, 1976, Geologic map of Georgia: Atlanta, scale 1:500,000.

Jennings, C.W., 1977, Geologic map of California: Sacramento, California Division of Mines and Geology, scale 1:750,000.

Kover, A., and Jones, J.E., 1986, The U.S. Geological Survey's side-looking airborne radar program; more progress, an update: Technical Papers, 1986 ACSM-ASPRS Annual Convention, v. 5, p. 211-212.

Moore, G.K., and Sheehan, C.A., 1981, Evaluation of radar imagery for geologic and cartographic applications: U.S. Geological survey Open-File Report 81-1358, $37 \mathrm{p}$.

Palmer, L.A., 1967, Marine terraces of California, Oregon, and Washington [University of California, Los Angeles, Ph.D. Dissertation]: University Microfilms, Inc., Ann Arbor, Michigan, 379 p.

Place, J.L., 1984, Mapping of forested wetland: uses of Seasat radar images to complement conventional sources: U.S. Geological survey Open-File Report 84-312, 14 p.

U.S. Geological Survey, 1969, Generalized geologic map of the Santa Barbara Channel region: U.S. Geological Survey Professional Paper 679, plate 1 , scale 1:250,000. 